\title{
Landslide Factors and Susceptibility Mapping on Natural and Artificial Slopes in Kundasang, Sabah
}

(Faktor Tanah Runtuh dan Pemetaan Kerentanan ke atas Cerun Semula Jadi dan Buatan di Kundasang, Sabah)

\author{
KAMILIA SHARIR, RODEANO RosleE, LEE KHAI ERN \& NORBERT SIMON*
}

\begin{abstract}
This study was carried out on the hilly topographic area in Kundasang, Sabah. This area is known to be extremely prone to landslides that occurred either naturally or by human interference to natural slopes. Aerial photographs interpretation was conducted in order to identify landslide distributions across three assessment years (2012, 2009 and 1984). These datasets were classified into two landslides groups based on their occurrences; natural and artificial. A total of 362 naturally occurring landslides were identified and another 133 are artificial slope landslides. Physical parameters which include lithology, slope angle, slope aspect and soil series were analyzed with each landslide group to examine the different influence of these parameters on each of the group. From the analysis, the landslide density for the natural landslide group shows that more than $35^{\circ}$ slope angle and slope aspect facing east and southwest are prone to landslides. In terms of geological materials, high landslide density is recorded in the phyllite, shale, siltstone and sandstone lithologies group and the Pinosuk, Kepayan and Trusmadi soil series. In contrast, for the artificial slope landslide, high landslide density is observed in the $25^{\circ}-35^{\circ}$ slope angle and similar density in every slope aspect classes. The geological materials however have similar landslide density across their factors'classes. The landslide density technique was also used to generate the landslide susceptibility maps for both landslide conditions. Validation of the maps shows acceptable accuracy of $71 \%$ and $74 \%$, respectively, for both natural and artificial slope landslide susceptibility maps and this shows that these maps can be used for future land use planning.
\end{abstract}

Keywords: Artificial slope landslide; landslide; landslide density; landslide susceptibility; natural landslide

\section{ABSTRAK}

Kajian ini dijalankan di kawasan bertopografi tinggi yang terletak di Kundasang, Sabah. Kawasan ini terkenal dengan kejadian tanah runtuh tinggi yang berlaku secara semula jadi ataupun secara gangguan oleh manusia pada cerun semula jadi. Penafsiran fotograf udara telah dilakukan untuk mengenal pasti taburan tanah runtuh sepanjang tiga tahun penilaian (2012, 2009 dan 1984). Set data ini telah dikelaskan kepada dua kumpulan tanah runtuh berdasarkan kepada punca berlakunya tanah runtuh, sama ada secara semula jadi atau pada cerun buatan. Sejumlah 362 tanah runtuh semula jadi telah dikenal pasti manakala 133 tanah runtuh lagi berlaku di cerun buatan. Parameter fizikal; litologi, sudut kecuraman cerun, aspek cerun dan siri tanah dianalisis bersama dengan setiap kumpulan tanah runtuh untuk melihat perkaitannya pada setiap kumpulan tersebut. Daripada analisis yang dibuat, ketumpatan tanah runtuh dalam kumpulan tanah runtuh semula jadi menunjukkan bahawa, sudut kecuraman cerun melebihi $35^{\circ}$ dan aspek cerun yang menghadap arah timur dan barat daya mempunyai tahap kerentanan tanah runtuh yang tinggi. Daripada segi bahan geologi pula, ketumpatan tanah runtuh yang tinggi direkodkan dalam batuan jenis filit, syal, batu lodak dan batu pasir serta jenis tanah daripada siri Pinosuk, Kepayan dan Trusmadi. Bagi ketumpatan tanah runtuh yang berlaku di cerun buatan manusia pula, ketumpatan tinggi direkodkan pada sudut kecuraman cerun $25^{\circ}-35^{\circ}$ dan hampir sama dalam setiap kelas aspek cerun.Daripada segi bahan-bahan geologi pula, ketumpatan tanah runtuh adalah hampir sama dalam semua kelas jenis batuan dan siri tanah. Teknik ketumpatan tanah runtuh ini juga digunakan untuk menghasilkan peta kerentanan tanah runtuh untuk kedua-dua set data ini. Pengesahan peta ini menunjukkan nilai ketepatan yang boleh diterima iaitu $71 \%$ dan $74 \%$ masing-masing untuk peta kerentanan tanah runtuh semula jadi dan cerun buatan manusia dan ini menunjukkan peta-peta ini boleh digunakan dalam perancangan guna tanah pada masa hadapan.

Kata kunci: Kerentanan tanah runtuh; ketumpatan tanah runtuh; tanah runtuh; tanah runtuh cerun buatan; tanah runtuh semula jadi

\section{INTRODUCTION}

Landslide susceptibility is defined as the tendency of an area to induce landslides (Guzzetti et al. 2006) or, it can also be defined in a mathematical form, which is, the probability of spatial occurrence of known slope failures, in a set of geo-environmental conditions (Guzzetti et al. 2005). Therefore, the aim of susceptibility analysis was to evaluate unstable slopes according to their causal 
factors (Ayalew et al. 2005). The combination of landslide initiation zones, with temporal and spatial probability will results in a landslide hazard map (van Western et al. 2003). This study was carried out to identify the susceptibility of landslide by taking into account the conditions in which landslides have occurred. This is important because different landslide conditions (natural or artificial slopes) might be induced by different landslide causal factors. Therefore, if both landslides in natural and artificial slopes were induced by different causal factors, the creation of landslide susceptibility maps for both landslide conditions will also be different. Moreover, it is advisable to analyse natural and artificial slope landslides separately (Australian Geomechanics Society 2007; Fell et al. 2008).

In this study, all landslides data were obtain from landslide inventory maps from three assessment years starting from 2012, 2009 and 1984. The database was divided into two groups ('naturally occurring landslides' and 'landslide in artificial slope'). These landslides were analysed independently using landslide density technique.

\section{SETTINGS OF THE STUDY AREA}

The study area is located in Kundasang, which is located in the Northwest of Ranau, Sabah (Figure 1). This area is well-known for its unstable hilly topographic terrain. This area was selected because of the abundance of landslides that often occurred due to natural causes and also from human interventions on its natural surroundings. The study area covers the latitude from $6^{\circ} 2^{\prime} 27.129^{\prime \prime} \mathrm{N}$ to $5^{\circ} 54^{\prime} 36.652^{\prime \prime} \mathrm{N}$, and from longitude $116^{\circ} 38^{\prime} 35.095^{\prime \prime} \mathrm{E}$ to $116^{\circ} 44^{\prime} 40.472$ 'E. The total study area is $426 \mathrm{~km}^{2}$.

The hilly terrain and ridges with an elevation of more than $1500 \mathrm{~m}$ (a.s.l) are combinations of steep to very steep slopes and was a direct after-effect of violent tectonic activities in the past (Roslee et al. 2012; Tating 2006). The

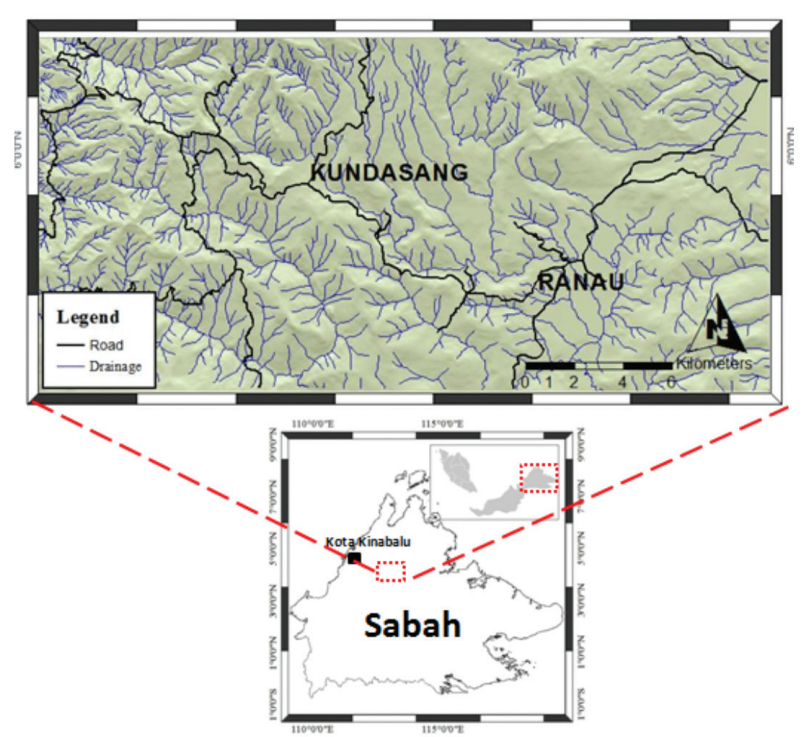

FIGURE 1. The study area steep and hummocky terrain, regional and unstable local geology and existence of old landslide areas, makes it an area prone to landslides (Roslee et al. 2012).

Crocker Formation (Late Eocene to Early Miocence age) and Trusmadi Formation (Paleocene to Eocene age) are the substantial rock formations in the study area. Besides these sedimentary and meta-sedimentary formations, granite intrusion and as well as several recent Quaternary alluvial materials which are still being deposited can also be found in the study area (Roslee et al. 2008). The Crocker Formation is divided into four main lithological units which are thick bedded sandstones, thinly bedded sandstone and siltstone, red and dark shale and slumped deposits. Rock sequence in the Trusmadi Formation was divided by Jacobson (1970) into four main lithological units, namely; argillaceous rocks, turbidites sequences, cataclasites and subphylite possibly derived from tuff. Massive sandstones units were later added by Tongkul (2007) to the rock sequence in the Trusmadi Formation. The alluvium is limited to the low land which represents unconsolidated alluvial sediments on river terraces that contain unsorted to well-sorted sand, silt and clay of varying propotions, which are mostly derived from the upstream bedrocks (Roslee et al. 2008; Tongkul 2007).

\section{METHODS}

In order to assess landslide susceptibility for an area, it is necessary to identify and map both landslide causal factors and landslide locations. In this study, these activities consist of three stages; creating landslide inventory via the interpretation of aerial photographs; selecting landslide causal factors based on their importance and data availability and generating landslide susceptibility map and determine the relationship of each of the causal factors' classes with landslide occurrences using landslide density technique. The Hufschmidt and Crozier's (2008) landslide density method was used to examine the influence of development. The landslide density calculation formula is:

$$
\text { Landslide density }=\frac{\text { Landslide count in each factor class }}{\text { Area occupied by the factor class }} \text {. }
$$

The landslide inventory was produced via the interpretation of aerial photographs. The landslide inventory is used to store the data on the landslides, in precise the location and areal extent of each landslide (Simon et al. 2017). A total of 178 aerial photographs were used to map landslides with the scale of 1:12 000 throughout three assessment years, starting from 1984, 2009 and 2012. The size, type, activity and conditions (natural or artificial slopes) were recorded during the interpretation. The aerial photographs in 1984 are in black and white, while the 2009 and 2012 aerial photographs are available in colour.

In this research, the landslide data for the three assessment years were combined for analysis. Subsequently, 
the landslides were separated into two groups based on the conditions in which they occurred: natural and artificial slopes. The natural and artificial slopes landslides were classified based on where they were occurred. Landslides that occurred in forest areas that are far from human disturbances were classified as natural and for those landslides that occurred very close to developed area and agricultural area were grouped as landslides in artificial slopes. These conditions were assumed through aerial photo interpretations.

In order to minimize errors in landslides identification, only landslide with visible scars observed in the photographs were extracted. From the dataset, 133 landslides were identified as artificial slope landslides and the other 362 landslides were occurred naturally (Figure 2). All landslides were digitized in a point format in GIS environment.

\section{LANDSLIDE INVENTORY}

The landslide size for natural and artificial slopes is different. The average size for the naturally occurring landslide is $13,780 \mathrm{~m}^{2}$ with sizes ranging from 588 to $90,967 \mathrm{~m}^{2}$, whereas, the average landslide size for the artificial slope landslide is smaller than the natural landslide ranging from 233 to $77,342 \mathrm{~m}^{2}$ with an average of $11,518 \mathrm{~m}^{2}$. Most of large landslides were observed to have occurred naturally (Table 1).

\section{SELECTION OF LANDSLIDE CAUSAL FACTORS}

The landslide causal factors used for the analysis were selected based on their influence on landslide occurrences. Distribution and trend of landslides differ due to various generic and specific factors (Thanapackiam et al. 2012).
They were four factors considered in contributing to the land sliding process as follows: Slope angle, slope aspect, lithology and soil type. As stated by Ayalew et al. (2005) and Yalcin (2008), there are no universal guidelines for selecting landslide causal factors in landslide susceptibility mapping. The selection of causal factors takes the nature of the study area and data availability into account. Therefore, factors were analyzed using landslide density method.

In order to analyze using landslide density, all data must be in categorical data. Hence, to categorize interval data in this study, the factor map for each factor was intersected with landslide inventory map to produce landslide distribution-factor map. This process is conducted to assign weight to each class in the factor map to determine which of the classes in each factor have higher influence to induce landslides and also for generating the landslide susceptibility map. Apart from that, weighting using density or area proportion to distinguish between different landslide susceptibility levels is much easier with categorical data (Simon 2012).

\section{SLOPE ANGLE AND SLOPE ASPECT}

Slope angle is one the most important causes of landslides (Ayalew \& Yamagishi 2005; Guzetti et al. 1999; Kolat et al. 2006; Ohlmacher \& Davis 2003; Oyagi 1984; Süzen \& Doyuran 2004; Zezere et al. 1999). It also has a great influence on the susceptibility of slope to land sliding (Dai \& Lee 2012). The slope angle (Figure 3) and slope aspect (Figure 4) was derived from a $20 \times 20 \mathrm{~m}$ resolution Digital Elevation Model (DEM) and further classified into four classes based on the Department of Mineral and Geosciences (Malaysia) classification; less than $15^{\circ}, 15^{\circ}$ $25^{\circ}, 25^{\circ}-35^{\circ}$ and more than $35^{\circ}$.

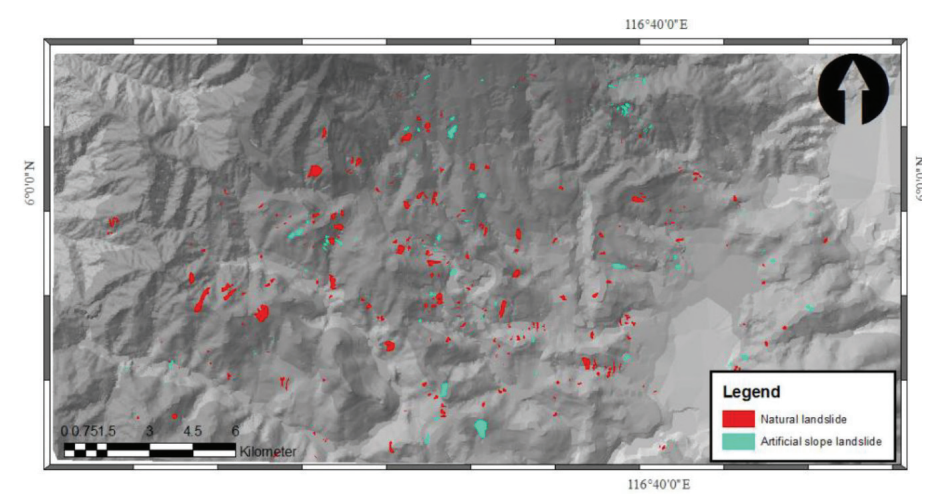

FIGURE 2. Landslide inventory in the study area

TABLE 1. Landslide datasets from 1984, 2009 and 2012 for natural and artificial slopes

\begin{tabular}{lccccc}
\hline \multirow{2}{*}{ Condition } & \multirow{2}{*}{ Total landslide } & Average area $\left(\mathrm{m}^{2}\right)$ & \multicolumn{2}{c}{ Type of landslide } \\
\cline { 4 - 6 } & & & Flow & Slide & Complex \\
\hline Natural landslide & 362 & $13780 \mathrm{~m}^{2}$ & 140 & 212 & 10 \\
Artificial slope landslide & 133 & $11518 \mathrm{~m}^{2}$ & 42 & 88 & 3 \\
\hline
\end{tabular}




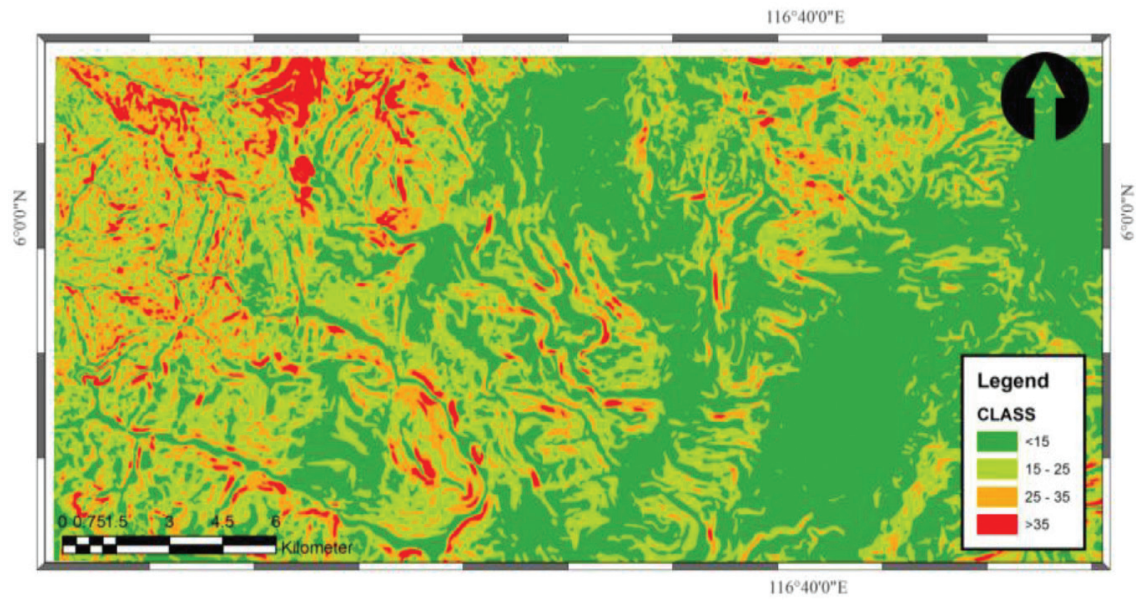

FIGURE 3. Slope angle in degree

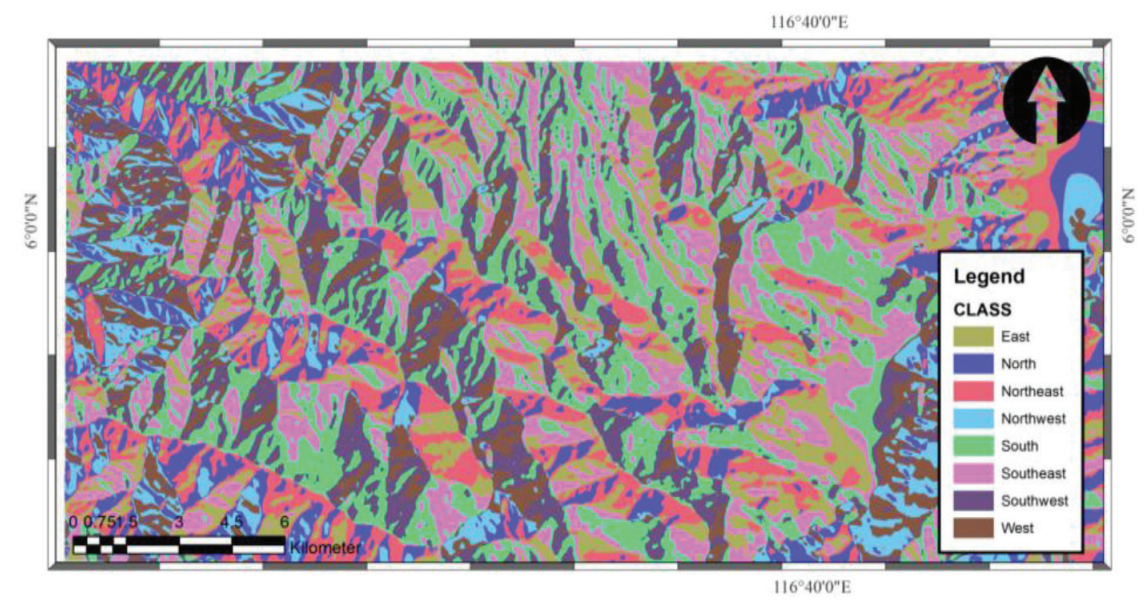

FIGURE 4. Classification of the slope aspect

Another essential landslide controlling factor is aspect, as aspect-related parameters (for instance the exposure to sunlight and drying winds) control the soil moisture concentration which has the ability to control landslide occurrences (Ayalew et al. 2005; Wieczorek et al. 1997; Yalcin 2008). Therefore, it is often used together with other landslide causal factors to generate a landslide susceptibility map (Ayalew et al. 2005; Dai et al. 2001; Guzzetti et al. 1999; Komac 2006; Nagarajan et al. 2000; Süzen \& Doyuran 2004; Yalcin 2008). The slope aspect was divided into eight classes: East, southeast, south, southwest, west, northwest and northeast.

\section{GEOLOGICAL MATERIALS (LITHOLOGY \& SOIL TYPES)}

Lithology and soil types are very important, as they are the top factors that are able to influence the type and intensity of geomorphologic processes, which can also induce landslides (Magliulo et al. 2008). The information about the lithology in the study area was derived from the 1:500 000 geological map of Sabah produced by the Department of Mineral and Geosciences, Malaysia and the information on soil types was derived from 1:250 000 map published by the Land Resources Department, Sabah.
The lithological map (Figure 5) was grouped into five main lithological classes: Flysch type sandstone, shale, siltstone with rare tuff, limestone, breccia and agglomerate (F); shale and phyllite with some siltstone and sandstone (SP); adamellite and granodiorite (AII); terrace sand, gravel and coral (TS); gabbro, dolerite, serpentinite, peridotite, dunite and pyroxenite (BUI); and coastal and riverine alluvium mainly clay, silt and sand (CRA). For soil types map (Figure 6), it was grouped into eleven soil series; Brantian, Kepayan, Labau, Bidu Bidu, Lokan, Malubok, Dalit, Trusmadi, Crocker, Pinosuk and Mentapok. Table 2 shows the parent material for each soil series.

\section{RESULT AND DISCUSSION}

This study uses slope angle, slope aspect, lithology and soil series as indicator to quantify the influence of physical parameter on landslide occurrences across the assessment years. Through this study, the landslide density was calculated in each of the selected physical parameter and the relationship across the assessment years can be observed (Table 3). 

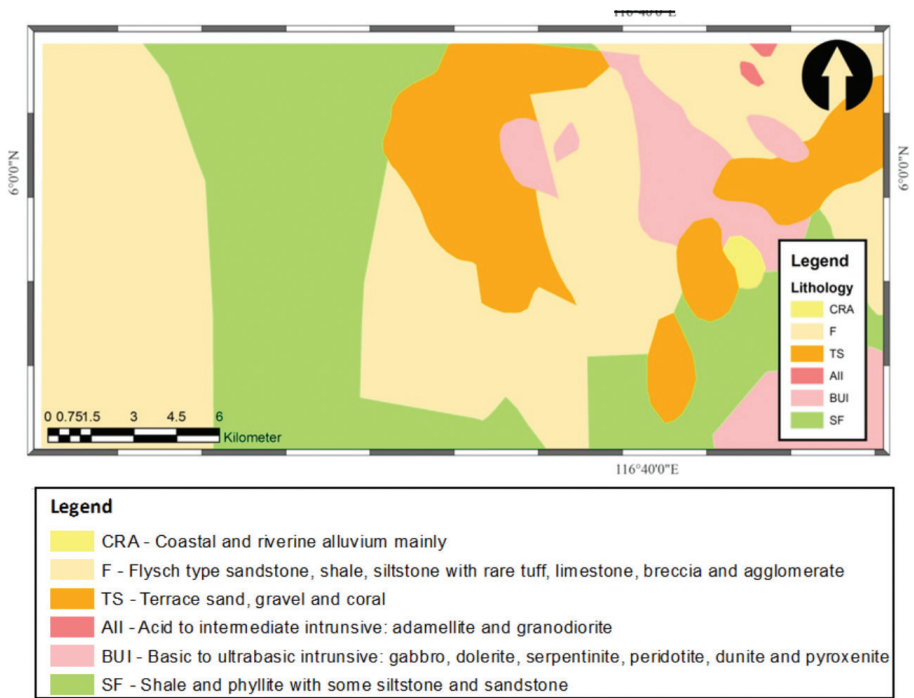

FIGURE 5. Lithological map of the study area

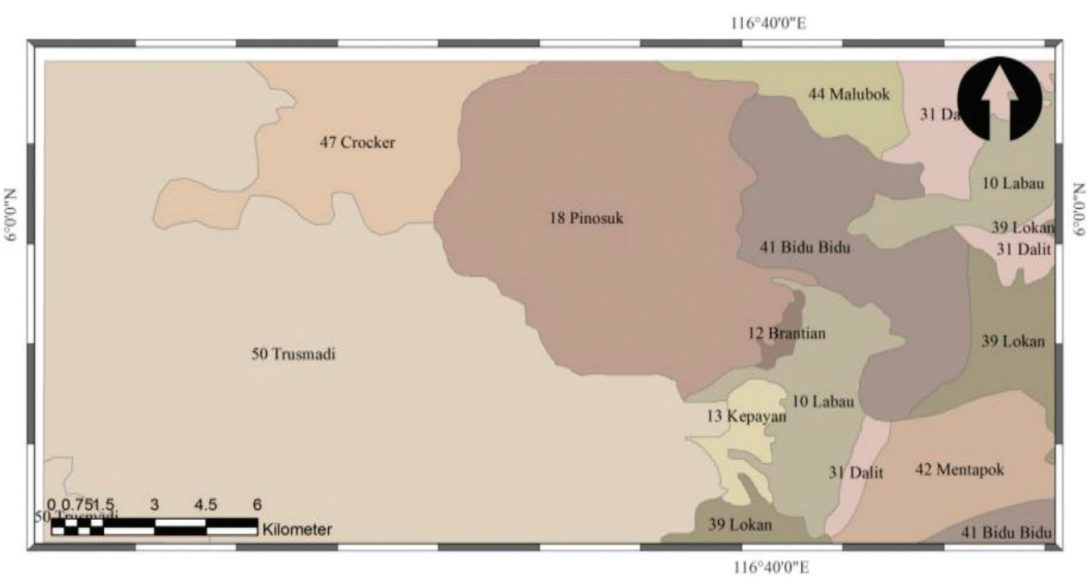

FIGURE 6 . Soil series map of the study area

TABLE 2. The parent material for each soil series

\begin{tabular}{ll}
\hline Soil series & Parent material \\
\hline Bidu Bidu & Ultrabasic igneus rocks \\
Brantian & Alluvium \\
Crocker & Sandstone, mudstone \\
Dalit & Sandstone, mudstone, alluvium \\
Kepayan & Alluvium \\
Labau & Alluvium \\
Lokan & Sandstone, mudstone \\
Malubok & Igneus rock, sandstone, mudstone, chert \\
Mentapok & Ultrabasic to intermediate igneus rock \\
Pinosuk & Colluvium, sandstone \\
Trusmadi & Sandstone, mudstone \\
\hline
\end{tabular}

\section{SLOPE ANGLE AND SLOPE ASPECT}

Slope angle has a strong impact on the susceptibility of a slope to land sliding (Dai \& Lee 2002). Based on the landslide density calculated for the natural landslide against slope angle categories (Figure 3), it was observed that the landslide density is prominent in the $>35^{\circ}$ category. The landslide density in the artificial slope group shows higher landslide density in the $25^{\circ}-35^{\circ}$ slope angle category. Natural landslides tend to increase as slope become steeper as observed in the study area (Gomez \& Kavzoglu 2007; Jadda et al. 2009). Soils at higher slope angle areas are subjected to shear stress and may prone to land sliding 
TABLE 3. Landslide density in each factor class

\begin{tabular}{|c|c|c|c|c|c|}
\hline \multirow[t]{2}{*}{ Class } & \multirow[t]{2}{*}{ Area $\left(\mathrm{km}^{2}\right)$} & \multicolumn{2}{|c|}{ No. of landslide } & \multicolumn{2}{|c|}{$\begin{array}{c}\text { Landslide density } \\
\text { (no. of landslides } / \mathrm{km}^{2} \text { ) }\end{array}$} \\
\hline & & $\begin{array}{l}\text { Natural } \\
\text { landslide }\end{array}$ & $\begin{array}{l}\text { Artificial slope } \\
\text { landslide }\end{array}$ & $\begin{array}{c}\text { Natural } \\
\text { landslide }\end{array}$ & $\begin{array}{l}\text { Artificial slope } \\
\text { landslide }\end{array}$ \\
\hline \multicolumn{6}{|c|}{ Slope Angle $\left({ }^{\circ}\right)$} \\
\hline$<15$ & 198 & 56 & 12 & 0.28 & 0.06 \\
\hline $15-25$ & 150 & 162 & 40 & 1.08 & 0.27 \\
\hline $25-35$ & 65 & 140 & 77 & 2.15 & 1.18 \\
\hline$>35$ & 13 & 56 & 4 & 4.31 & 0.31 \\
\hline \multicolumn{6}{|c|}{ Slope Aspect } \\
\hline East & 58 & 57 & 12 & 0.98 & 0.21 \\
\hline North & 43 & 39 & 9 & 0.91 & 0.21 \\
\hline Northeast & 53 & 36 & 14 & 0.68 & 0.26 \\
\hline Northwest & 30 & 14 & 8 & 0.47 & 0.27 \\
\hline South & 79 & 73 & 38 & 0.92 & 0.48 \\
\hline Southeast & 66 & 47 & 20 & 0.71 & 0.30 \\
\hline Southwest & 59 & 72 & 25 & 1.22 & 0.42 \\
\hline West & 39 & 24 & 7 & 0.62 & 0.18 \\
\hline \multicolumn{6}{|l|}{ Soil Series } \\
\hline Bidu Bidu & 37 & 28 & 19 & 0.76 & 0.51 \\
\hline Brantian & 1 & 2 & 7 & 2.00 & 7.00 \\
\hline Crocker & 30 & 16 & 1 & 0.50 & 0.0 \\
\hline Dalit & 19 & 5 & 1 & 0.28 & 0.06 \\
\hline Kepayan & 5 & 7 & 3 & 1.40 & 0.60 \\
\hline Labau & 31 & 14 & 3 & 0.47 & 0.10 \\
\hline Lokan & 18 & 4 & 0 & 0.22 & 0.00 \\
\hline Malubok & 10 & 0 & 1 & 0.00 & 0.10 \\
\hline Mentapok & 19 & 0 & 0 & 0.00 & 0.00 \\
\hline Pinosuk & 73 & 75 & 45 & 1.03 & 0.62 \\
\hline Trusmadi & 185 & 211 & 53 & 1.1 & 0.30 \\
\hline \multicolumn{6}{|l|}{ Lithology } \\
\hline AII & 1 & 0 & 0 & 0.00 & 0.00 \\
\hline BUI & 43 & 17 & 11 & 0.40 & 0.26 \\
\hline CRA & 2 & 4 & 4 & 2.00 & 2.00 \\
\hline $\mathrm{F}$ & 184 & 172 & 61 & 0.93 & 0.33 \\
\hline SP & 134 & 119 & 36 & 0.89 & 0.27 \\
\hline TS & 64 & 50 & 21 & 0.78 & 0.33 \\
\hline
\end{tabular}

which can be seen in natural landslides dataset. This is because as slope angle increases, resistance is reduced and shear stress is increased. However, this rule seems does not apply in the artificial slope group. Most landslides in this group appear to be in the $25^{\circ}-35^{\circ}$ slope angle category. The reason for this is most of the developed area are concentrated on this slope category, thus increases the tendency of this slope category to fail.

Slope aspect can influence landslide initiation by retaining moisture in a slope as it is usually associated with moisture retention and vegetation, which in turn may affect soil strength and susceptibility to landslides (Wieczorek et al. 1997). For natural landslides, higher landslide density was recorded on slope facing east and southwest (Figure 4). In contrast, the artificial slope landslide group showed similar landslide density in all its slope aspect categories which means that development have taken place in all directions of slopes in the study area. Disregarding slope aspect in development planning may contribute to hazard of land sliding as development may trigger landslides on slope directions that are naturally susceptible to landslides. In this case, east and southwest aspects of the study area were more naturally susceptible to land sliding compared to other directions.

\section{GEOLOGICAL MATERIALS (LITHOLOGY AND SOIL SERIES)}

The properties of the slope-forming materials are related to the lithology and soil type, which are important factor in initiating landslides (Dai \& Lee 2002). From Figure 5 , the CRA group of lithology are more susceptible to 
landslide than other groups. However, based on its area coverage (Table 3), it is not substantial compared to other lithologies, which in this case are the F, SF \& TS that covered large part of the study area. Therefore, in terms of landslide density it can be inferred that the F, SF and TS lithologies are the most susceptible with the highest in $\mathrm{F}$ and $\mathrm{SF}$ groups for the natural landslide dataset. These two groups contain higher percentage of fine grain and easily weathered rock types such as shale, phyllite, siltstone and sandstone, which have higher susceptibility to landslide (Ohlmacher 2000; Rib \& Ta 1978). On the artificial slope group however, no definite pattern of landslide density was observed as all lithology showed similar susceptibility to landslide.

Soil series played an important role in providing information about the physical properties of the soil that contributes to land sliding. From Table 3, it can be observed that the Brantian soil group has the highest landslide density in both natural and artificial slope groups. However, this soil group is not a substantial group due to its small area. Based on the calculated landslide density, higher density was observed in the Kepayan, Trusmadi and Pinosuk soil series for the natural landslide group as oppose to the artificial slope group where landslide density is distributed almost evenly in all soil series, although higher landslide density can be observed in the Kepayan and Pinosuk soil series. These soil series are made of sandstone, mudstone and colluvial materials. Soil originated from mudstone is mostly fine grain with high clay content. Colluvial material on the other hand referred to loose sedimentary materials transported from top to the base of hillslopes. These materials are therefore highly prone to landslide than other materials in the soil series. Table 4 shows the summary of the physical parameters that are associated with landslides in both natural and artifcial slope groups.

\section{LANDSLIDE SUSCEPTIBILITY ASSESSMENT}

The landslide density method was also used to generate the landslide susceptibility maps for both landslide conditions. Before computing the landslide susceptibility map, the landslide inventory was divided randomly into two datasets; training dataset containing $70 \%$ of the total landslides (natural: 253 landslides; artificial slope: 93 landslides) and validation dataset consists the remaining 30\% landslides (natural: 109 landslide; artificial slope: 40 landslides). The training dataset was used to generate the landslide susceptibility map for each of the landslide conditions based on their own number of landslides. These landslides were intersected with the landslide factor maps which later were overlaid to produce the final landslide susceptibility map.

The landslide susceptibility maps for both natural and artificial slope are shown in Figures 7 and 8. These maps were classified into three classes of susceptibility: low, moderate and high using the natural break classification. The area of different susceptibility levels and number of landslides in both training and validation datasets for each landslide conditions are presented in Table 5. The validation of each map was conducted by calculating the percentage of landslides that are inside of the high landslide susceptibility class. Based on the validation testing of the maps, the natural and artificial slope groups recorded $71 \%$ and $74 \%$ accuracy, respectively. This level of accuracy which is almost similar to other studies (Chalkias et al. 2014; Guzetti et al. 2006) indicate that both maps can be used as preliminary maps to designate areas with high potential for landslides to occur. Once the landslide susceptibility data has been assessed, the data set can be expanded and this result can be used as a future disaster prevention reference (Yang \& Yeh 2015).

As observed in Figures 7 and 8, both maps show the northern part of the study area are highly susceptible to landslide because of its high topography, steep slopes and made of fine grain geological materials such as shale, phyllite, siltstone, sandstone and flysch type rocks. The Pinosuk soil group is also abundant in this part of the study area. The artificial landslide susceptibility map however, differ slightly in its distribution of high susceptibility class, where its scatter to almost every part of the study area. The reason for this is because there are three factors (lithology, slope aspect \& soil series) that have similar landslide density in every factor's class, which may contribute to the way the high susceptibility class is distributed.

TABLE 4. Natural and artificial slope susceptibility map with the physical parameter involve

\begin{tabular}{ll}
\hline Susceptibility maps & Physical parameters involve \\
\hline Natural & - Slope angle: $>35^{\circ}$ \\
& - Slope aspect: East and southwest \\
& - Lithology: F and SF \\
& - Soil series: Kepayan, Crocker and Pinosuk \\
& - Slope angle: $25^{\circ}-35^{\circ}$ \\
Artificial & - Slope aspect: similar in all categories \\
& - Lithology: similar in all categories \\
& - Soil series: similar in all categories \\
\hline
\end{tabular}




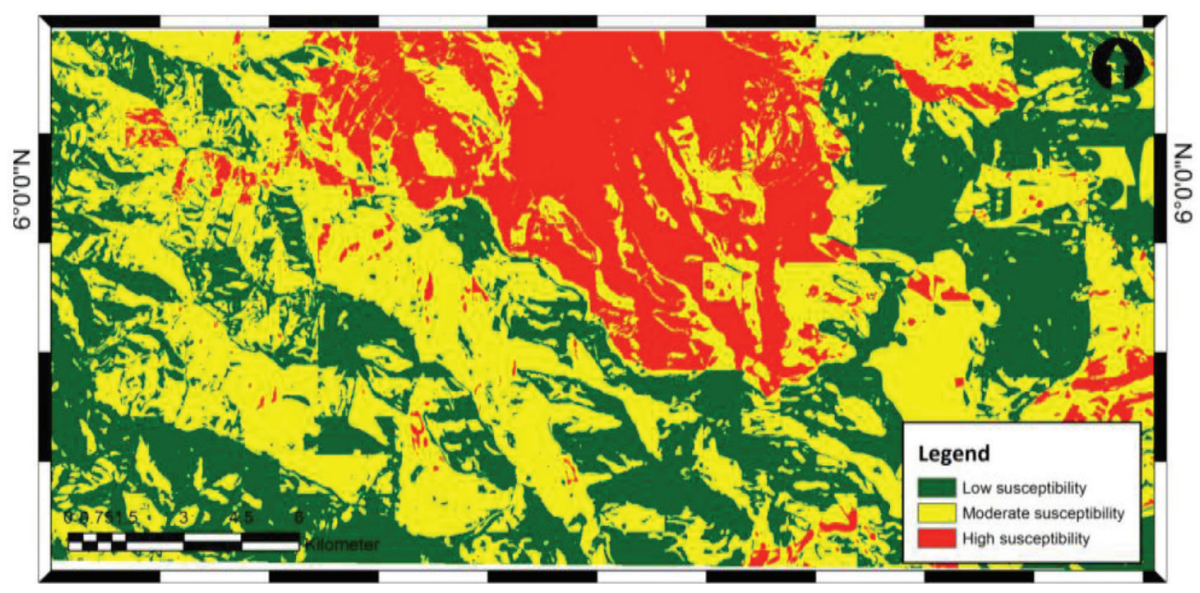

FIGURE 7. Natural landslide susceptibility map

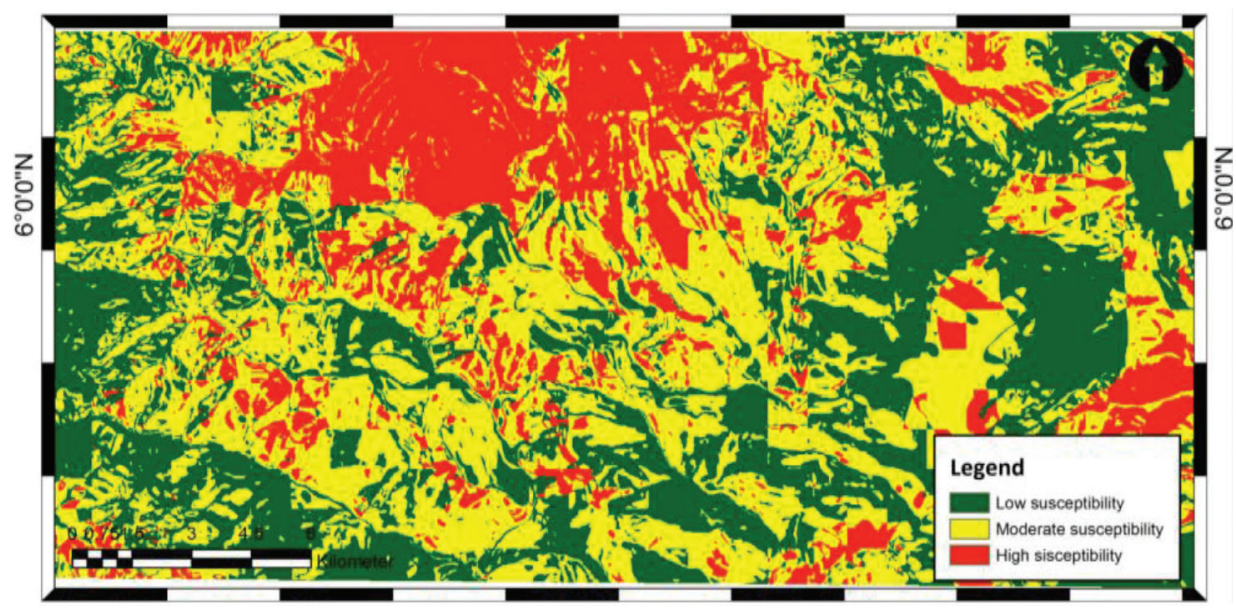

FIGURE 8. Artificial landslide susceptibility map

TABLE 5. Distribution of landslides (training and validation datasets in each of the landslide susceptibility maps)

\begin{tabular}{lccc}
\hline (a) $\begin{array}{l}\text { Natural landslide susceptibility } \\
\text { index }\end{array}$ & Area $\left(\mathrm{Km}^{2}\right)$ & $\begin{array}{c}\text { No. of landslide } \\
\text { (training dataset) }\end{array}$ & $\begin{array}{c}\text { No. of landslide } \\
\text { (validation dataset) }\end{array}$ \\
\hline Low & 141 & 64 & 29 \\
Moderate & 181 & 125 & 25 \\
High & 78 & 64 & 55 \\
Percentage (\%) & & 82 & 71 \\
\hline (b) Artificial slope landslide & Area $\left(\mathrm{Km}^{2}\right)$ & No. of landslide & No. of landslide \\
susceptibility index & & (training dataset) & (validation dataset) \\
\hline Low & 93 & 22 & 7 \\
Moderate & 112 & 33 & 21 \\
High & 39 & 36 & 74 \\
Percentage $(\%)$ & & 92 & \\
\hline
\end{tabular}

\section{CONCLUSION}

In this study the evaluation of relative importance of each factor to landslide occurrence has been done by using landslide density method. Based on the natural landslide susceptibility map, slope angle categories between $>35^{\circ}$, slope aspect facing east and southwest, S and SF lithologies and soil series of Kepayan, Trusmadi and Pinosuk are highly prone to landslide than any other categories in each of the landslide factors. In contrast, the artificial slope landslide showed different susceptible categories to land sliding in each of the landslide factor. The slope angle of $25^{\circ}-35^{\circ}$ category has higher landslide density than other 
categories in the same factor, while the landslide density is similar in almost all categories in the slope aspect, lithology and soil series factor. The landslide susceptibility maps for both datasets were validated and the fact that the validation accuracies are $71 \%$ for the natural and $74 \%$ for the artificial landslide susceptibility maps, both maps may be used for future land use planning to minimise damages caused by landslides because they are in the range of acceptable accuracy.

\section{ACKNOWLEDGEMENTS}

This paper presents part of research program funded by the Government of Malaysia under grant (GUP-2014-031). The authors would also like to acknowledge the support of the staff and facilities at Geology Program, Universiti Kebangsaan Malaysia and Universiti Malaysia Sabah.

\section{REFERENCES}

Australian Geomechanics Society. 2007. Guideline for landslide susceptibility, hazard and risk zoning for land use planning. Australian Geomechanics 42(1): 13-36.

Ayalew, L. \& Yamagishi, H. 2005. The application of GIS-based logistic regression for landslide susceptibility mapping in the Kakuda-Yahiko Mountains, Central Japan. Geomorphology 65: 15-31.

Ayalew, L., Yamagishi, H., Marui, H. \& Kanno, T. 2005. Landslides in Sado Island of Japan: Part II. GIS-based susceptibility mapping with comparisons of results from two methods and verifications. Eng. Geol. 81: 432-445.

Chalkias, C., Ferentinou, M. \& Polykretis, C. 2014. GISbased landslide susceptibility mapping on the Peloponnese Peninsula, Greece. Geosciences 4: 176-190.

Dai, F.C. \& Lee, C.F. 2002. Landslide characteristics and slope instability modelling using GIS, Lantau Island, Hong Kong. Geomorphology 42: 213-228.

Dai, F.C., Lee, C.F., Li, J. \& Xu, Z.W. 2001. Assessment of landslide susceptibility on the natural terrain of Lantau Island, Hong Kong. Environ. Geol. 40: 381-391.

Gomez, H. \& Kavzoglu, T. 2005. Assessment of shallow landslide susceptibility using artificial neural networks in Jabonosa River Basin, Venezuela. Engineering Geology 78: 11-27.

Guzzetti, F., Reichenbach, P., Ardizzone, F., Cardinali, M. \& Galli, M. 2006. Estimating the quality of landslide susceptibility models. Geomorphology 81(1-2): 166-184.

Guzzetti, F., Reichenbach, P., Cardinali, M., Galli, M. \& Ardizzone, F. 2005. Landslide hazard assessment in the Staffora basin, northern Italian Apennines. Geomorphology 72: 272-299.

Guzzetti, F., Carrara, A., Cardinali, M. \& Reichenbach, P. 1999. Landslide hazard evaluation: A review of current techniques and their application in a multi-scale study, Central Italy. Geomorphology 31: 181-216.

Hufschmidt, G. \& Crozier, M.J. 2008. Evolution of natural risk: Analysing changing landslide hazard in Wellington, Aotearoa/New Zealand. Natural Hazards 45: 255-276.

Jabcoson, G. 1970. Gunung Kinabalu area, Sabah, Malaysia. Geol. Surv. Malaysia. Report 8: 111.

Jadda, M., Shafri, H.Z.M., Mansor, S.B., Sharifika, M., \& Pirasteh, S. 2009. Landslide susceptibility evaluation and factor effect analysis using probabilistic-frequency ratio model. European Journal of Scientific Research 33(4): 654-668.

Fell, R., Corominas, J., Bonnard, C., Cascini, L., Leroi, E., Savage, W.Z. on behalf of the JTC-1 Joint Technical Committee on Landslides and Engineered Slopes 2008. Guidelines for landslide susceptibility, hazard and risk zoning for land use planning. Engineering Geology 102: 85-98.

Kolat, C., Doyuran, V., Ayday, C. \& Süzen, M.L. 2006. Preparation of a geotechnical microzonation model using geographical information systems based on multicriteria decision analysis. Eng. Geol. 87: 241-255.

Komac, M. 2006. A landslide susceptibility model using the analytical hierarchy process method and multivariate statistics in perialpine Slovenia. Geomorphology 74: 17-28.

Magliulo, P., Antonio, D.L., Filippo, R. \& Antonio, Z. 2008. Geomorphology and landslide susceptibility assessment using GIS and bivariate statistics: A case study in southern Italy. Natural Hazards 47(3): 411-435.

Nagarajan, R., Roy, A., Vinod, K.R., Mukherjee, A. \& Khire, M.V. 2000. Landslide hazard susceptibility mapping based on terrain and climatic factors for tropical monsoon regions. Bull.Eng. Geol. Env. 58: 275-287.

Ohlmacher, G.C. \& Davis, J.C. 2003. Using multiple logistic regression and GIS technology to predict landslide hazard in northeast Kansas, USA. Eng. Geol. 69: 331-343.

Ohlmacher, G.C. 2000. The relationship between geology and landslide hazards of Atchison, Kansas and Vicnity. Current Research in Earth Sciences: Kansas Geological Survey Bulletin 244: 1-6.

Oyagi, N. 1984. Landslides in weathered rocks and residuals soils in Japan a surrounding areas: State-of-the-art report. Proceedings of the 4th International Symposium on Landslides, Toronto. pp. 1-31.

Rib, H.T. \& Ta, L. 1978. Recognition and identification. In Landslides Analysis and Control, Special Report, edited by Schuster, R.A. Washington: National Academy of Science. 176: 34-80.

Roslee, R., Jamaluddin, T.A. \& Talip, M.A. 2012. Landslide susceptibility mapping (LSM) at Kota Kinabalu, Sabah, Malaysia using factor analysis model (FAM). Journal of Advanced Science and Engineering Research 2: 80-103.

Roslee, R., Tahir, S., Zawawi, N.S.A., Mansor, H.E. \& Omang, S.A.K.S. 2008. Engineering geological assessment on slope design in the mountainous area of Sabah Western, Malaysia: A case study from the Ranau - Tambunan, Penampang Tambunan and Kimanis - Keningau Road. An International Conference on Recent Advances in Engineering Geology. Kuala Lumpur, Malaysia.

Süzen, M.L. \& Doyuran, V. 2004 . Data driven bivariate landslide susceptibility assessment using geographical information systems: A method and application to Asarsuyu catchment Turkey. Eng. Geol. 71: 303-321.

Simon, N., De Roiste, M., Crozier, M. \& Rafek, A.G. 2017. Representing landslides as polygon (areal) or points? How different data types influence the accuracy of landslide susceptibility maps. Sains Malaysiana 46(1): 27-34.

Simon, N. 2012. Developing a systematic approach to susceptibility mapping for landslides in natural and artificial slopes in an area undergoing land use change, Kota Kinabalu, Sabah, Malaysia. Ph.D Thesis. Victoria University of Wellington (Unpublished).

Tating, F. 2006. Geological factors contributing to the landslide hazard area at the Tamparuli - Ranau Highway, Sabah, 
Malaysia. Proc.of International Symposium on Geotechnical Hazards: Prevention, Mitigation and Engineering Response. Yogyakarta, Indonesia. p. 10.

Thanapackiam, P., Khairulmaini, O.S. \& Fauza, A.G. 2012. Space-time behavior of Klang Valley region slope failures. Sains Malaysiana 41(12): 1613-1620.

Tongkul, F. 2007. Geological inputs in road design and construction in mountainous areas of West Sabah, Malaysia. Second Malaysia-Japan Symposium on Geohazards and Geoenvironmental Engineering Recent Advances. Langkawi, Malaysia.

van Westen, C.J., Rengers, N. \& Soeters, R. 2003. Use of geomorphological information in indirect landslide susceptibility assessment. Nat. Hazards 30: 399-413.

Wieczorek, G.F., Mandrone, G. \& De Colla, L. 1997. The influence of hill slope shapes on debris-flow initiation. In Debris Flow Hazard Mitigation: Mechanics, Prediction, and Assessment, edited by Chen, C.L. New York: American Society of Civil Engineers. pp. 21-31.

Yalcin, A. 2008. GIS-based landslide susceptibility mapping using analytical hierarchy process and bivariate statistics in Ardesen (Turkey): Comparisons of results and confirmations, Turkey. Catena 72: 1-12.

Yang, S. \& Yeh, Y. 2015. Geologic hazard risk assessment of slopeland villages in Southern Taiwan using remote sensing techniques. Sains Malaysiana 44(12): 1677-1683.

Z^ezere, J.L., de Brum, F.A. \& Rodrigues, M.L. 1999. The role of conditioning and triggering factors in the occurrence of landslides: A case study in the area north of Lisbon (Portugal). Geomorphology 30: 133-146.
Kamilia Sharir \& Norbert Simon*

School of Environmental and Natural Resource Sciences Faculty of Science \& Technology

Universiti Kebangsaan Malaysia 43600 UKM Bangi, Selangor Darul Ehsan Malaysia

Rodeano Roslee

School of Science \& Technology

Universiti Malaysia Sabah, UMS Road

88400 Kota Kinabalu, Sabah Negeri di Bawah Bayu

Malaysia

Lee Khai Ern

Institute for Environment and Development (LESTARI)

Universiti Kebangsaan Malaysia

43600 UKM Bangi, Selangor Darul Ehsan

Malaysia

*Corresponding author; email: norbsn@ukm.edu.my

Received: 9 December 2016

Accepted: 2 May 2017 